than that of his face. His irides were light brown. He, too, did not seem to suffer from photophobia.

An albino boy, named Kilapelama, aged about 10 years, seen at Bulaa on the south-east coast of British New Guinea, had, with a light, greenish-brown iris, an especially pinkwhite skin covered with short, fine, almost downy white hairs. Scattered over the whole of the body there were a number of irregularly circular patches of dark pigment, varying in size from that of a split pea to that of a sixpenny bit (Figs. 2 and 3). The periphery of a certain number of these showed irregular dendritic processes of pigment. On drawing the finger over the skin no difference in texture could be perceived between the general surface and the pigmented patches; the latter, which were, if anything, rather darker and more bronzed than the skin of a normal Bulaa man, seem to be of the same character as those seen in the Vaturua case described by the American Expedition. Mr. Norman $\mathrm{H}$. Hardy has given me a photograph he obtained in Sydney of the head and upper half of the body of a man of Aoba in the New Hebrides in whom the black spots are so numerous as to produce a speckled appearance; the colour of the hair is not recorded, but judging from the photograph it was not of the usual black colour. Other instances of the same condition have been described by Finsch. They were observed at Bulaa and in his paper already alluded to full details of Bulaa and Kerepunu albinos will be found.

There exists also a somewhat less-marked type of albinism in which greenish eyes and tow-coloured hair accompany skin of a pale café-au-lait colour. Two examples of this condition were seen at Jokea in the persons of a boy about 18 years of age and his paternal uncle. They were both lean, muscular, active, and energetic and the boy was of rather unusual intelligence. Neither suffered from photophobia to any marked degree nor was their skin harsh or thickened to the touch. This form would seem to denote a transition to those individuals not uncommon among the Papuans of Torres Straits in whom the skin is a shade or two lighter than is normally the case, their eyes being brownish and distinctly lighter than the normal dark colour. Their hair, too, is less dark and in the men this may be specially obvious in regard to their moustaches. The condition tends to be hereditary ; all the children born to a Mabuiag couple, both members of which were of this type, were specially light-coloured.

Partial albinism is rare. Only one case was seen and in FIG. 4.

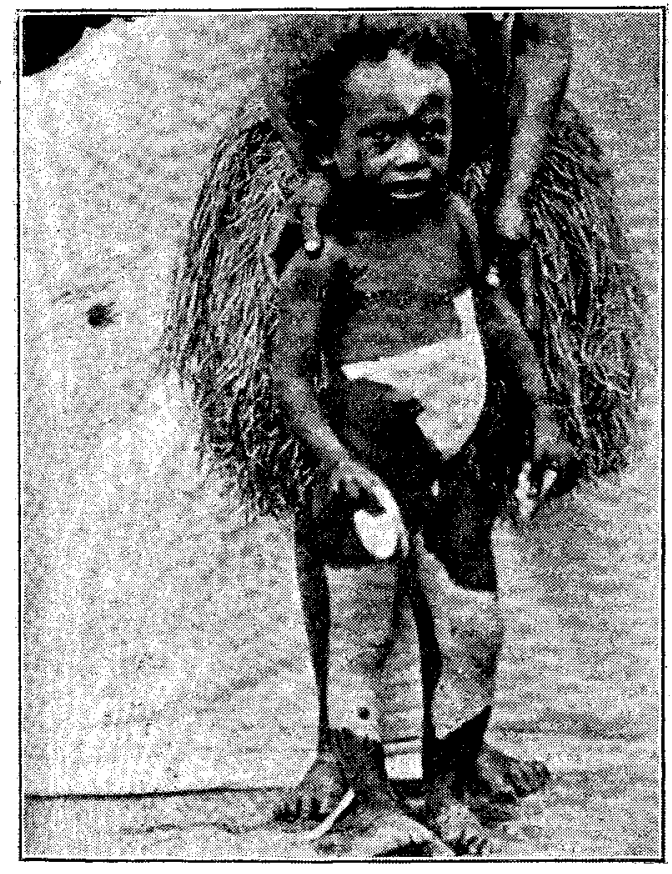

Partial albinism in a Papuan boy.

this, contrary to general experience, there was marked symmetry on the two sides of the body. The case was that of a Sinaugolo boy, aged about four years (Fig. 4), on whose trunk there was a large white patch; there was another somewhat diamond-shape flare on his forehead reaching on to the hairy scalp where the hairs were white. There were almost symmetrical patches just above the elbows on the back of the arm, while on both legs there were white areas extending from just above the ankles to the mid-thigh. Dotted about these there were a few small roughly circular areas of normally black skin. There was no family history of albinism of any grade or of any unusual skin condition. My thanks are due to Mr. A. C. English, Government Agent of the Rigo district, who kindly photographed this case for me. The heaped-up ulcer on the abdomen is the remains of a yaw tubercle.

Leucoderma, which, as already stated, is remarkably common and is generally distributed throughout New Guinea and Torres Straits as in other localities, tends to be symmetrical and is a disease of middle and advanced life. The borders of the white patches are always sharp and the bleaching is not as a rule preceded by an increased deposit of pigment. In one case only-that of an old woman, one of the very few natives still left on the island of Nagir in Torres Straits-was the skin at the edges of, and between the pale patches on, the hand and forearm distinctly darker than over the rest of the body. In all cases which were seen the disease was limited to the limbs, beginning always at the distal extremities and spreading slowly upwards, seldom reaching higher than the middle of the tibia in the lower limb or than the middle of the upper arm in the upper limb. The disease attacked the dorsum of the foot and the flexor surface of the wrist or hand far more commonly than the plantar and extensor surfaces respectively and very commonly began accurately opposite the flexure of the wrist, thence spreading up and down the limb. In no case could any alteration of sensation or any trophic change be detected in the affected areas, nor was there any evidence of the change being due to vegetable parasites.

St. Thomas's Hospital, S.E.

\section{PERSISTENT HEREDITARY EEDMA OF THE LOWER LIMBS.}

By H. D. ROLleston, M.D. CantaB., F.R.C.P. Lond, PHYSICIAN TO ST. GEORGE'S HOSPITAL; SENIOR PHYSICIAN TO OUT-PATIENTS, VICTORIA HOSPITAL FOR CHILDREN; EXAMINER IN MEDICINE IN THE UNIVERSTTY OF DURHAM.

I HAVE recently had under my care in St. George's Hospital a brother and a sister (patients of Dr. H. Hollis of Wellingborough) who were both the subjects of a peculiar form of œdema of the legs. The cedema was permanent as long as they led an ordinary life and got more marked after exercise or a warm bath, but disappeared after rest in bed for some days. It was only troublesome from the weight and size of the swollen legs and did not give rise to pain or to any other bad results. The mother, aged 45 years, who had suffered for 35 years from the same condition. had long ceased to think of her own legs and was only concerned for her children. There were five other children, both older and younger, but they were not subject to swollen legs or to chilblains. None of the mother's brothers or sisters survived infancy and this condition, which had apparently been transmitted from the mother to her two children, could not be traced any further. There was no history or trace of syphilitic infection in any of the patients, Some years ago a fatty tumour had been removed from one thigh of the mother by Mr. A. A. Bowlby. There was no evidence of hæmophilia. The cedema was limited to the lower extremities and chiefly to the legs and feet. It varied, as already pointed out, gradually increasing when the patients were up and slowly receding when they remained for some days in bed, but there was no sudden appearance of the swelling as in angioneurotic cedema. When the limbs were kept warm the skin was natural in colour, but the circulation was very feeble, pressure on the skin leaving an anæmic area for a much longer time than in normal persons. The cedematous skin pitted fairly readily and was distinctly cold to the touch. In appearance the skin was quite free from any structural change; there was no thickening such as is seen in elephantiasis. The absence of any such change in the mother in whom œdema had existed for 35 years was remarkable. There was no tenderness on pressure over the swollen parts. There was no puffiness of the face, hands, or any part of the body except the lower extremities. 
No recognised cause tor oedema was forthcoming in any of the three patients. Examination of the heart showed nothing abnormal and there was no anæmia; in fact, in both the brother and sister the number of red blood corpuscles was $5,800,000$ per cubic millimetre. The urine was healthy; there had been no hæmoglobinuria, and no signs of pressure on the inferior vena cava, or of lymphatic obstruction, venous thrombosis, or peripheral neuritis could be found. They bad not been out of England and had never had erysipelas, and they were not subject to urticaria or to any yastro-intestinal disturbance such as is common in angio-neurotic cedema. There was, however, evidence of what was popularly called "a feeble circulation." At birth they were both "blue children," and were very subject to chilblains, both the feet and hands readily getting livid by cold. When the skin was in this condition it resembled the stage of local asphyxia in Raynaud's disease. The phenomena of local syncope, gangrene of the extremities, or hæmoglobinuria, bad not, so far as history and observation went, occurred in these two patients. The lividity and blueness of the hands were exaggerated, as in erythromelalyia, when they were allowed to hang down, and diminished when they were elevated. But there was no pain or tenderness assocrated with the lividity, thus differing from erythromelalgia. Pressure on the congested skin lelt an anæmic area for a considerable time. The patients were healthy-looking, intelligent, thin, and perhaps a little small for their ages. A few further details may be recorded about their condition.

The girl was aged 16 years. Swelling of the legs began three years ago and had been constant except when confined to bed for a tew days. When the legs had been bandaged the œdema had mounted to the thighs. On July 8th the following measurements were taken : the left calf, maximum measurement, $13 \frac{1}{2}$ inches circumference; the right calf, maximum measurement, $16 \frac{1}{2}$ inches circumference. A fortnight later, after being in bed most of the time, the right calf measured 12 inches and the left $11 \frac{1}{2}$ inches in its maximum circumference. The urine was healthy. The blood showed $5,830,000$ red and 16,000 white corpu-cles per cubic millimetre ; a differential count showed a slight diminution of the polymorphonuclears and a corresponding increase in the lymphocytes. Blood-pressure at the wrist taken with Barnard's sphygmometer was 125 millimetres of mercury, or just about the normal.

The boy was aged 13 years. His legs began to swell three years ago. The odema occupied both legs and ascended about half-way up the left thigh. On admission, on May 28th, the following measurements were taken : left calf, maximum, $12 \frac{3}{4}$ inches circumference ; right calf, maximum, 13 inches circumference. On June 13th, after rest in bed with the end of the bed raised by blocks and treatment with ergot and digitalis in small doses, and galvani-m, as practised by Sir T. Barlow ${ }^{1}$ in Raynaud's disease, the maximum circum. ference of the right calf was 11 inches and that of the left was $11 \frac{3}{4}$ inches. The skin of the legs showed no structural change and no resemblance to elephantiasis. The creasing of the skin above the ankles shown in the photograph, kindly taken by Mr. J W. Mercer, was due to the pressure exerted by boots. The knee-jerks and sen-ation were normal. On exposure to cold the extremities became cyanotic ; this was exaggerated when the hands were allowed to hang down. 'The specific gravity of the blood was 1056 and the bloodpressure, taken when the hands were warm by Mr. Golla by Barnard's sphygmometer, was 95 willimetres of mercury, or below the normal The red blood corpuscles were $5,800,000$ and the white 16,000 per cubic millimetre, with a diminution in the polymorphonuclear and an increase in the mononuclear torms. The urine was natural. On July 22 nd he unfortunately developed scarlet fever and was transferred to a tever hospital.

Treatment consisted in rest in bed with elevation of the bed, and though drugs and the application of the constant current to the odematous legs on the lines indicated by Sir 'T. Barlow in Raynaud's disease were employed, position appeared to be the only thing which really had any definite effect on the cedema. Small doses of digitali and ergot were given with the intention of improving the vascular tone.

Remarks. - The occurrence of hereditary angioneurotic cedema is well known. Osler ${ }^{2}$ has given a descriptiun

1 Allbutt's System of Medicine, vol. vi., p. 605.

2 American Journal of the Medical Sciences, vol. xcv., p. 362, 1888. of a family in which that disea-e was present in five generations, and quite recently Wardrop Grifith ${ }^{3}$ has recorded a case of hereditary angioneurotic cedema which suddenly proved fatal from acute laryngeal cedema. The cases under my care differed entirely from angioneurotic œdema and superficially present more resemblance to the cedema of cardiac disease or of chlorosis. But there is no evidence that the cellema can be referred to either of these causes. The cases appear to resemble the remarkable family described by Milroy ${ }^{+}$of Omaha in whicb

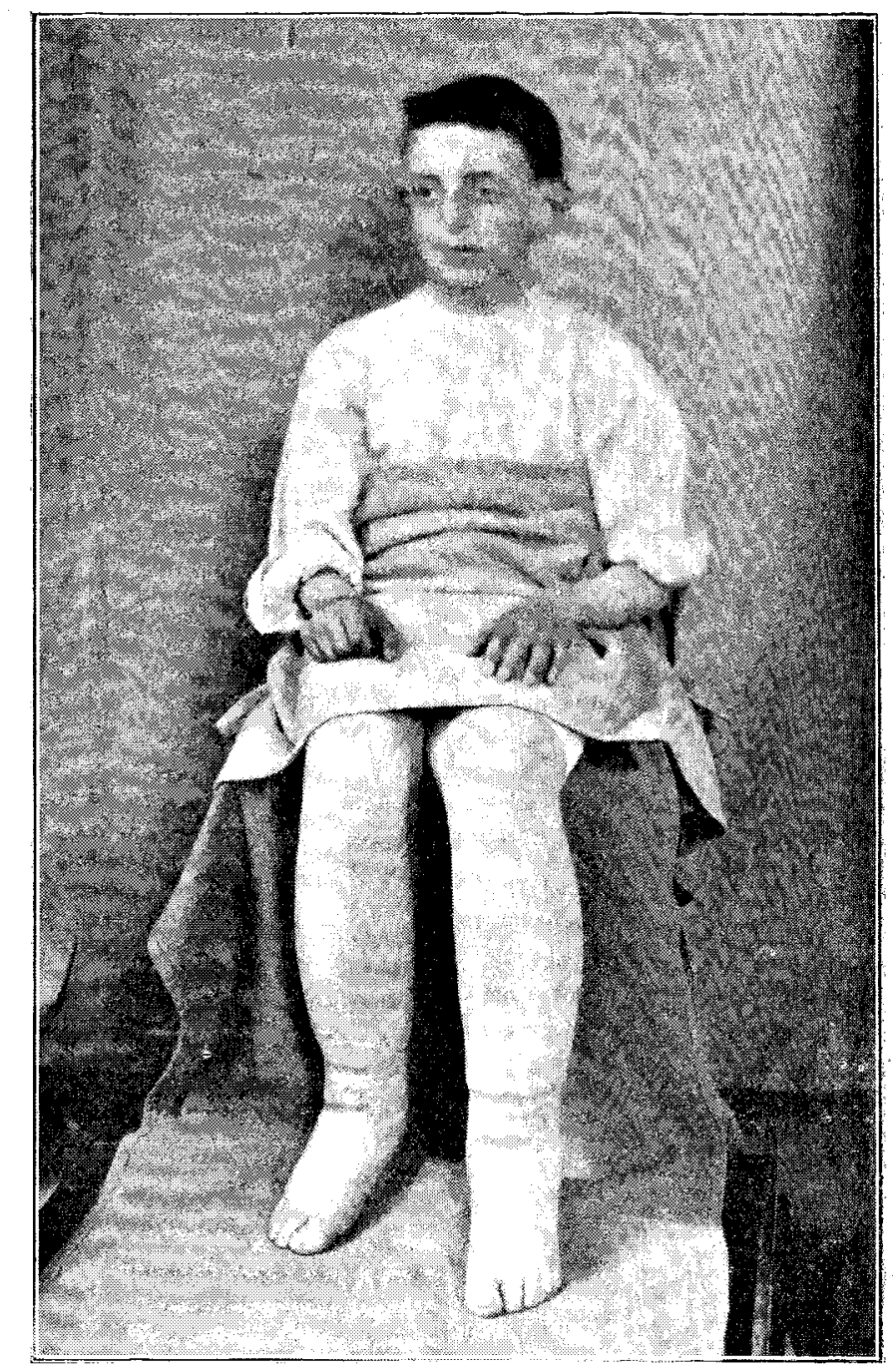

Shows persistent hereditary cedema of the feet, legs, and left thigh, and cyanotic condition of the bands. The creasing of the skin curove the ankles was temporary and was due to of the skin above the ankles was temporary and was due to hours before the boot. The patient had been ap for some hours before the photograph was taken in order to increase
the amount of odema.

out of 97 individuals in six generations 22 persons (12 males, seven females, and three unknown) had solid cedema of one or both legs without any special inconvenience or progressive increase in the disease. The condition was congenital except in one case, in which it developed at the age of 12 years. In one case only d:d the cedema disappear even tempolarily. Crozier Griffith and Newcome, ${ }^{5}$ in their paper on Types of Gdema in Infancy and Childhood, report a case which they regard as allied in some respects to Milroy's cases. In a child, aged four years, cedema of the face and left leg developed at three months of age after measles. Milroy, after very tentatively suggesting that the condition might depend on a congenital absence of valves in the veins, came to the conclusi. $n$ that it was more closely allied to angioneurotic cedema than to any other known disease. My cases, however, differ from Milroy's in developing at or after 10 years of age. They are therefore hereditary but not congenital in addition, as were all but one of Milroy's.

3 Brit. Merl. Jour., 1902, vol. i., p. 1170.

4 An Unlescrlhed Variety of Hereditary CEdema, New York Medical Journal Niv. 5th. 1892.

5 Transdetions of the Association of American Physicians, vol. xii., p. 411 . 
The disease in some respects resembles both Raynalid's disease and erythromelalgia but differs from them, as has already been pointed out, in many essential particulars.

The pathogeny of this curious condition offers a wide and tempting field for speculation. It misht be suggested that the persistent tendency to cedema from gravitation depends on some inherent defect or peculiarity of the small bloodvessels, which allows excessive transudation to occur on very slight provocation. Isolated examples of œedema for which no satisfactory cause can be found come under observation from time to time. I had a case of this apparently idiopathic cdema in a healthy young woman, aged 24 years, under my care in St. George's Hospital last year, and I have heard of a few other cases in women. Edema of obscure origin is less rare in the newly-born and in very young children and may be due to a number of different causes, but some of the cases where no satisfactory cause is forthcoming may be sporadic examples of the condition described by Milroy.

The object of this paper has been to attract attention to a definite group of cases characterised by per-istent cedema of the lower extremities which is hereditary and may be congenital but does not depend on any of the factors ordinarily recognised as responsible for cedema.

Lpper Brook-street, $W$.

\section{MUCIN AND MALIGNANCY: FACTS AND THEORIES.}

By WILLIAM STUART-LOW, F.R.C.S. ENG.,

ASSISTANT REGISTRAR TO THE CENTRAL LONDON THROAT AND EAR HOSPITAL.

No substance in the animal economy has been more despised and neglected of medical men than mucin, but it may yet be destined to become the head of the corner. Mucus has ever been the butt and bete noir of the physician whose every effort has always been strenuously put forth to brush, to wash, and to dissolve it away as an evil thing, serving only to harbour organisms and to retard and to jeopardise recovery from pathological conditions. How far wrong this depreciatory estimate of the value of mucin is an attentive study of its nature, functions, and probable ulterior destiny will amply bear out. Mucin is the substance that gives the sliminess to mucus. It is very largely present in the system and is found under two conditions-first, almost universally distributed as the cementing material between cells-tissue mucin. This separates connective tissue cells and endothelial and epithelial cells even where most closely approximated. Normally, there is al ways a layer, however thin, of muciginous material which separates the constituent cells in every tissue and membrane throughout the body; and secondly, mucin is found on all murous membranes in mucous glands and in many epithelial and all special goblet cells, conspicuously so in the surface cells of the stomach wall where every cell is mucus secreting.

There are probably several mucins in the body. They are of a colloid nature, viscous, soluble in alkalies, but precipitable from such solutions by acetic acid. On boiling with dilute mineral acids they yield a substance which reduces Fehling's solution, and by appropriate processes mucin is broken up into a carbohydrate called animal gum and a nucleo proteid. Mucin has been specially investigated in the jelly-like connective tissue of the vitreous bumour, the Whartonian jelly, and in tendons While the part that mucin plays is doubtless largely mechanical in lubricating and protecting mucous surfaces, its peculiar chemical constitution and behaviour lend support to the belief that it has some further function. Physi. ologists mostly agree that mucin is not broken up in the digestive process but that it passes by the bowel unchanged. The very large amount secreted, however, and the comparatively small amount excreted would indicate that much is destroyed or absorbed in the small intestine, and the great additional supply in the large bowel supports this supposition; and further, nucleo-proteid, with its valuable percentage of phosphorus, being a result of mucin disintegration, the likelihood is that this is not thrown away but is absorbed from the intestine for ulterior use in the economy. Where mucin is found fulfilling ohiefly a lubricating function as in the gall-bladder and bile ducts, in the pancreatic duct, and the lower bowel, it has a distinctly alkaline reaction and is mixed with the contents passing over the mucous surface. On surfaces bathed by acid fluids, on the other hand, the mucin is diminished in alkalinity, and in this manner it is maintained on the surface proper for protective purposes; this is well seen in the case of the urinary passages where much mucus is present and necessary. Such is a wise provision, for should the urine become alkaline the mucus present in it becomes then a serious factor in treatment. In the stomach again the acid gastric juice maintains the mucus on the surtace, the protective function being paramount. On the mucous membrane of the nose and other air passages the mucus plays a most invaluable part. It maintains moisture and conserves warmth, thus facilitating sensation both common and special. It also keeps the membrane fit both to catch foreign bodies (dust, bacteria, \&c.) as the air filters through and rerves to secure such until the leucocytes can annihilate or remove them.

One of the mort imp rtant actions of mucin and one which has hitherto been altugether overlooked is as a bactericide. This germicidal power was proved in researches I bad carried out two years ago in the Laburatory of Clinical Pathology, Queen Anne-street, W., by Dr. G. L. Eastes. It was shown that mucin has a retarding influence on bacterial growth. that sterilised solutions containing mucin remained sterile for a long time on exposure to the air, and that bacteria ceased to grow in culture media when mixed with mucin. This is very interesting and instructive and proves that nature has in the secretion poured out on mucous membranes provided a ready means of suppressing bacterial growth. In the British Medical Journal of March 8th last there is an account (quoted from the Lynn Medical) of a research by Professor Fernand Arloing in which this work is repeated. From this he concludes that the mucus of redsnails has a bactericidal action on the bacillus of Löfller and other bacteria and nasal mucus was found to be a bactericide for staphylococcus and pneumococcus, but not for colibacteria or for Eberth's microbes. It must be evident, therefore, that mucin fulfils a potent part in the defence of the body against bacterial attack.

The essential lesion of carcinoma is the penetration of cells into the surrounding tissues, but whether this new departure on the part of the cells is a result of a cellular change or of some alteration in the intercellular resisting substance is not yet clear. The probability is that there is a certain degree of both. In old age the intercellular material undergoes a wasting change and as a re-ult of this its resistive power against the ingrowth of epithelial cells is lessened and thus the onset of carcinoma is favoured-particularly as the overlying epithelium remairs much longer active and thus there is an influence inducing the cells to penetrate inwards among the tissues. The centrosome in cells on epithelial mucous surfaces occupies that part of the cell nearest the surface and therefore the part most exposed to injury and irritation. The centrosome is the dynamic centre and plays the leading part in the division if the nucleus and the proliferation of the cell and the regulation of movement.

A study of the distribution of mucous manufacturing structures reveals the striking fact that where mucus is least abundant their malignant disease is most located. This is the case where skin and mucous membranes meet at the edges of orifices, as at the lips, prepuce, and anus ; in the pharynx below the middle, as there are many fewer mucous glands in this situation than in the upper part; and on the tonsil, where there are but few mucous glands or cells even in the crypts. Malignant disease is common in the upper third of the asophagus, where there are few mucous structures, and very common in the middle third, where there are practically none; it is least seen of any part in the lower third where mucous glands are numerous. The cesophagus is peculiar in being dependent almost entirely for its lubrication and protective coating on mucus passing down from above-from the nose and vault of the pharynx. I have observed a number of cases of malignant disease of the esophagus and in these there has been much diminution of mucous secretion from above shown by the deficient action of the mucous membranes of the nose and pharynx and always, too, chronic dyspepsia due to the same cause-too little mucous protective coating in the stomach. Maljgnant disease is most frequently situated in the stomach at the pyloric end, but although there is much mucous secretion here there are special reasons for this selection; it is the most dependent part and most subjected to injury by lumpy and improperly masticated fond, 